\title{
Clinicopathological Study of Male Breast Malignancy in a Tertiary Care Hospital, Bangladesh
}



Conflict of Interest: None

Received: $14-03-2019$

Accepted: $07-05-2019$

www.banglajol.info/index.php/JSSMC

\section{Key Words:}

Male breast Cancer (MBC),

Ductal carcinoma, Sarcoma,

Papillary carcinoma.

\begin{abstract}
:
Introduction: Male breast malignancy is a relatively rare condition among all the malignancies. It accounts for $0.2 \%$ of all malignant cases \& less than $1 \%$ of all breast cancer.
\end{abstract}

Methods and Materials: A retrospective observational study was done among the male patients with breast malignancy, admitted in Surgery ward in Shaheed Suhrawardy Medical College Hospital, Bangladesh from January 2014 to December, 2018.

Results: Our series includes 09 patients. The mean age of the patient was 60 years. Most of the patients complaint breast lump with some degrees of skin colour changes. One has previous history of breast surgery (lumpectomy). Eight (8) patients went under simple mastectomy with axillary clearance after tissue diagnosis. One (1) patient got neo- adjuvant chemotherapy followed by surgery. Specimen was sent for histopathological \& receptor study. Among them Infiltrating was ductal carcinoma was found in 07 cases, Sarcoma was in 01 (one) case \& papillary carcinoma in 01 (one) case with $66.6 \%$ positive oestrogen and progesterone receptor activity.

Conclusion: Surgeons should be kept in mind that male breast malignancy is not uncommon and all male breast lumps should be evaluated properly before surgery.

[J Shaheed Suhrawardy Med Coll 2019; 11(1): 48-51] DOI: https://doi.org/10.3329/jssmc.v11i1.43180

\section{Introduction:}

Breast cancer is one of the leading cause of death in females of Bangladesh and it is increasing day by day. Though male breast malignancy is relatively uncommon malignancy accounting for $<1 \%$ of all breast cancers in the western world $^{1,2}$. The incidence of male breast cancer (MBC) in Northwest Europe and North America is approximately 1/ 100,000 but is increasing day by day ${ }^{3}$. Disease frequency is higher among Jewish men at 2.3/100,000 and in countries with a high incidence of parasitic liver disease such as Egypt and Zambia ${ }^{4,5}$. In Bangladesh the rate of breast cancer

1. Dr. S M Quamrul Akther, Associate Professor, Surgery, ShSMCH, Dhaka

2. Dr. Ismat Jahan Lima, Assistant Professor, Colorectal Surgery, ShSMCH, Dhaka

3. Dr. Syed Masud Reza, Associate Professor, Surgery, ShSMCH, Dhaka

4. Dr. Md. Mozammel Hoque, Associate Professor, Surgery, ShSMCH, Dhaka

5. Dr. Fayem Chowdhury, Junior Consultant, Surgery, ShSMCH, Dhaka

6. Dr. Md. Safiqul Islam, Medical Officer, ShSMCH, Dhaka

7. Dr. Amit Sen Gupta, Assistant Register, ShSMCH, Dhaka

Correspondence to: Dr. S M Quamrul Akther, Associate professor, Surgery, Shaheed Suhrawardy Medical College Hospital, E mail: qu_sanju@yahoo.com occurrence is estimated to be 22.5 per 100000 females of all ages; In case of Bangladeshi women, aged between 15-44 years, breast cancer has the highest prevalence, 19.3 per 100000 compared to any other type of cancer 6 .

The causes of male breast malignancy mostly remain unknown, however several risk factors exist. There is a close relation between the BRCA2 gene mutation and male breast cancer. It has also been observed, that some cases involve BRCA1 participation ${ }^{7-9}$. Other conditions that have been associated with the occurrence of breast neoplasms in men are cirrhosis ${ }^{10}$, testicular trauma, obesity, radiation therapy exposure and the use of exogenous estrogen ${ }^{11}$. Male breast malignancy has not been studied as extensively as female breast cancer due to less number of cases and pathological specimens. Most studies related to $\mathrm{MBC}$ are retrospective analysis with a small number of patients; carcinoma is the most frequent histological type and the treatment of $\mathrm{MBC}$ is patterned on that of the females. The appearance of the cutaneous signs is the most frequent reasons for consultation in case of MBC. Because of ignorance \& negligence on the part of patients and some times of the referring physicians, they often seek medical treatment late.

The clinico-pathological characteristics, treatment patterns and outcomes of MBC were investigated in this study. 


\section{Methods:}

Retrospective analysis was designed to include patients admitted in surgery ward at ShSMCH from January 2014 to December 2018. The studied variable were data regarding general characteristics of patients (age, presenting signs \& symptoms, duration of symptoms, site $\&$ location of tumour), histopathology of tumour, and modalities of treatment and outcome.

\section{Results:}

The study included 09 patients. The mean age at presentation was 60 years, with standard deviation of 3.24 years and a range of 55-60 years. Most patients were found to have breast lumps detected on self-examination and sometimes noticed by others. But they visited to doctor when overlying skin colour changes in (07 cases) or suddenly increase in the size of lump (02 cases). 01 patient had positive family history. On clinical examination palpable lymph node was found in the axillary region in 04 cases \& mainly in left breast. There is no case of bilateralism. One had undergone previous surgery (lumpectomy)in breast in a district level hospital.

Histopathological results revealed ductal carcinoma in 07 cases, Sarcoma in 01 case and papillary carcinoma in 01 case. Hormonal receptor is carried out in ductal carcinoma patients. Four patients out of six patients were found positive for oestrogen and progesterone receptor.

Table 1

\begin{tabular}{lcc|ccc}
\multicolumn{5}{c}{ Age distribution of patients and size of lump } \\
Case no. & Age of patient & Tumour size $(\mathrm{cm})$ & Case no. & Age of patient & Tumour size (cm) \\
\hline 1 & 55 & 3 & 6 & 62 & 6 \\
2 & 63 & 3.5 & 7 & 63 & 2.5 \\
3 & 64 & 5 & 9 & 60 & 3 \\
4 & 58 & 2 & & & 3.8 \\
5 & 59 & 7 & 9 & & \\
\hline
\end{tabular}

Mean age: 60

SD: 3.24 yrs



Mean size of tumor is $3.97 \mathrm{~cm}$ The largest one is $7 \mathrm{~cm}$

Fig.-1: Bar diagram of involved site distribution

Table-II

\begin{tabular}{lcc}
\multicolumn{3}{c}{ Histological type of malignancy } \\
Histological type & Number & Percentage \\
\hline Ductal carcinoma & 7 & $77.77 \%$ \\
Papillary carcinoma & 1 & $11.11 \%$ \\
Sarcoma & 1 & $11.11 \%$ \\
\hline
\end{tabular}

Table-III

\begin{tabular}{lcc}
\multicolumn{3}{c}{ Staging of tumour: } \\
Staging & Number & Percentage \\
\hline II & 2 & 22.22 \\
IIIA & 3 & 33.33 \\
IIIB & 4 & 44.44 \\
\hline
\end{tabular}



Fig.-1: Carcinoma Breast

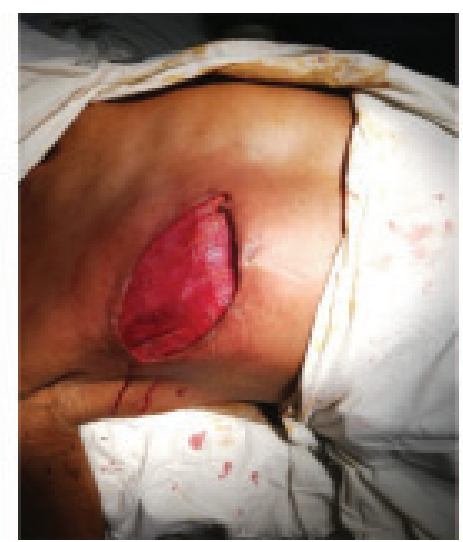

Fig.-2: Carcinoma Breast

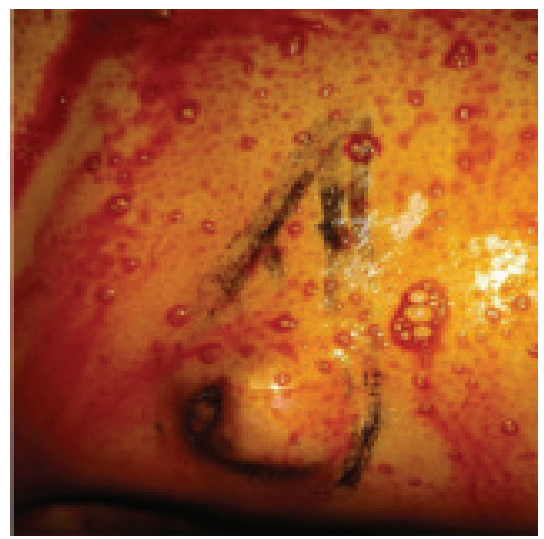

Fig.-3: After removal of specimen 


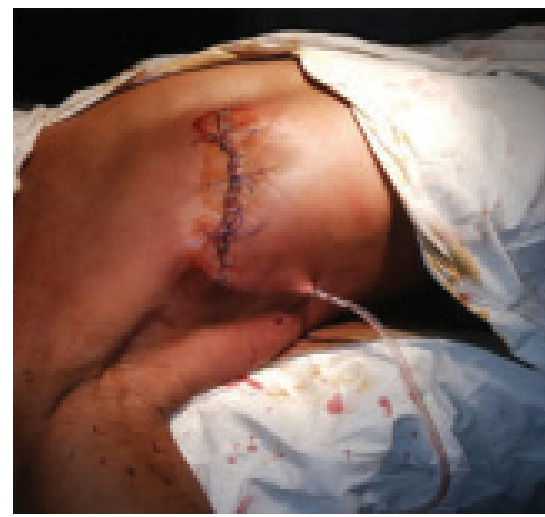

Fig.-4: Closure of wound tissue.

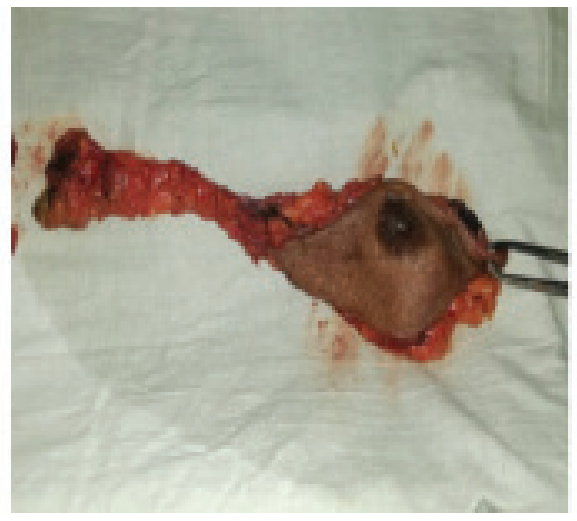

Fig.-5: Specimen of Ca-Breast

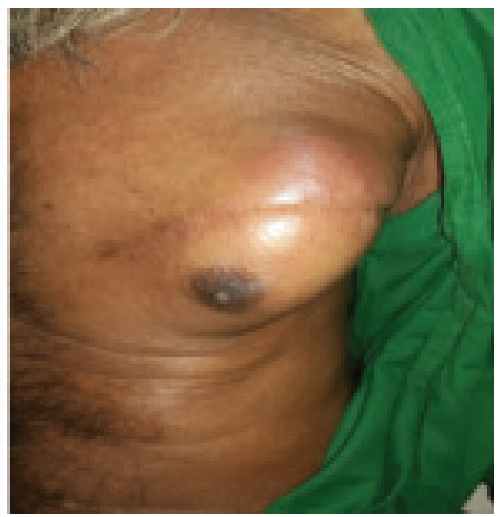

Fig.-6: Sarcoma of breast with axillary

Table-IV

Data of the malignancy of male breast patients admitted in ShSMCH

\begin{tabular}{|c|c|c|c|c|c|c|c|c|c|}
\hline $\begin{array}{l}\text { Data } \\
\text { Family History } \\
\text { of malignancy }\end{array}$ & $\begin{array}{c}1 \\
\text { Absent }\end{array}$ & $\begin{array}{c}2 \\
\text { Absent }\end{array}$ & $\begin{array}{c}3 \\
\text { Absent }\end{array}$ & $\begin{array}{c}4 \\
\text { Absent }\end{array}$ & $\begin{array}{c}5 \\
\text { Absent }\end{array}$ & $\begin{array}{c}6 \\
\text { Absent }\end{array}$ & $\begin{array}{c}7 \\
\text { Present }\end{array}$ & $\begin{array}{c}8 \\
\text { Absent }\end{array}$ & $\begin{array}{c}9 \\
\text { Absent }\end{array}$ \\
\hline \multicolumn{10}{|l|}{ Chief complaints } \\
\hline Lump & + & + & + & + & + & $\begin{array}{c}+ \\
\text { Recuurent }\end{array}$ & + & + & + \\
\hline $\begin{array}{l}\text { Overlying } \\
\text { skin colour } \\
\text { change }\end{array}$ & + & + & + & + & - & - & + & - & + \\
\hline
\end{tabular}

\section{Table-V}

\begin{tabular}{|c|c|c|c|c|c|c|c|c|c|}
\hline \multicolumn{10}{|c|}{ ????? } \\
\hline $\begin{array}{l}\text { Histological Grade } \\
\text { of tumour }\end{array}$ & 2 & 2 & 3 & 2 & 2 & 2 & 2 & 2 & 2 \\
\hline $\begin{array}{l}\text { Node Status } \\
\text { Receptor } \\
\text { status }\end{array}$ & $0 / 10$ & $2 / 10$ & $2 / 10$ & $0 / 10$ & NA & $\mathrm{NA}$ & $1 / 10$ & $0 / 10$ & $0 / 10$ \\
\hline $\begin{array}{l}\text { Oestrogen } \\
\text { receptor }\end{array}$ & + & + & + & - & NA & NA & NA & + & + \\
\hline $\begin{array}{l}\text { Progesterone } \\
\text { receptor }\end{array}$ & + & + & + & - & NA & NA & NA & + & + \\
\hline $\begin{array}{l}\text { Her-2 } \\
\text { status }\end{array}$ & negative & Negative & negative & Negative & NA & NA & NA & negative & Negative \\
\hline
\end{tabular}

\section{Table-VI}

Treatment of patients with breast cancer at ShSMCH

\begin{tabular}{lccccccccc} 
Therapeutic Options & 1 & 2 & 3 & 4 & 5 & 6 & 7 & 8 & 9 \\
\hline $\begin{array}{l}\text { Surgery(simple mastectomy } \\
\text { \& axillary clearance) }\end{array}$ & Yes & Yes & Yes & Yes & Yes & Yes & Yes & Yes & Yes \\
$\begin{array}{l}\text { Chemotherapy } \\
\text { Hormone Therapy }\end{array}$ & Yes & Yes & No & No & Yes & Yes & Yes & Yes & Yes \\
\hline
\end{tabular}




\section{Discussion}

Male breast malignancy is a rare disease but the incidence is increasing significantly along with the increasing incidence of female breast cancer. Geographic variations in the incidence of $\mathrm{MBC}$ were reported. In Europe, approximately $1 \%$ of all $\mathrm{BC}$ occurs in males, but the incidence is much higher in other areas such as subSaharan Africa with 5 to $15 \%$. The incidence of MBC in Northwest Europe and North America is approximately $1 /$ 100,000 but is increasing. ${ }^{3}$ Disease frequency is higher among Jewish men at 2.3/100,000 and in countries with a high incidence of parasitic liver disease such as Egypt and Zambia. ${ }^{4,5}$ In Japan, where the incidence of female breast cancer is low, the rate of $\mathrm{MBC}$ is $<0.5 / 100,000 .{ }^{6}$

The mean age of our study is 60 years, approximately one decade more than that of female in Bangladesh.

On staging of this disease in this study most of the patients are of stage III, which means an advanced stage of cancer. Several factors are responsible for this, including ignorance of patients, error in initial diagnosis which mostly confused with skin disease made diagnosis by nonmedical personnel.

Infiltrating ductal carcinoma is the most frequent invasive carcinoma in men, accounting for $66.67 \%$, while lobular carcinoma is rare due to lack of terminal lobules in male breast .The rare subtypes such as sarcoma, papillary carcinoma is also found in our study which is very uncommon in women. The node metastasis is present in 03 patients out of 09 patients. Oestrogen \& Progesterone receptor is present in $83 \%$ of patients in Ductal cell carcinoma in this study. The hormone-dependence of MBC is established, the hormonal receptors are positive in 65 to $90 \%$ of cases according to the series, those with estrogens in 65 to $86 \%$ and those with progesterone in 67 to $80 \%{ }^{12,13}$

The treatment protocol option of MBC is almost same as female breast cancer. But we have done surgery at first (Simple mastectomy with axillary clearance) in all stages of MBC. Then patients were advised to continue Chemotherapy but one patient refused. Though Hormone therapy is suitable for receptor positive patients but one patient denied this treatment. There is no history of recurrence among the patients till now. We do not offer radiotherapy due to all patients' undergone axillary clearance \& this may increase the morbidity of the patient.

\section{Conclusion:}

Male breast malignancy is not uncommon. Surgeons should keep in mind that all male breast lumps should be evaluated properly before surgery. Attending physician is also an important factor in diagnosis and proper referral of patient.

\section{References:}

1. Fentiman IS, Fourquet A, Hortobagyi GN. Male breast cancer. Lancet. 2006;367:595-604. doi: 10.1016/S01406736(06)68226-3. [PubMed] [CrossRef]

2. Gennari R, Curigliano G, Jereczek-Fossa BA, Zurrida S, Renne G, Intra M, Galimberti V, Luini A, Orecchia R, Viale G, Goldhrisch A, Veronesi U. Male breast cancer: a special therapeutic problem. Anything new? (Review) Int J Oncol. 2004;24:663-670. [PubMed]

3. Hodgson NC, Button JH, Franceschi D, et al. Male breast cancer: is the incidence increasing? Ann Surg Oncol. 2004;11(8):751-5. doi: 10.1245/ASO.2004.01. 001. [PubMed] [CrossRef]

4. El-Gazayerli MM, Abdel-Aziz AS. On bilharziasis and male breast cancer in Egypt: a preliminary report and review of the literature. Br J Cancer. 1963;17:566-71. [PMC free article] [PubMed]

5. Bhagwandin S. Carcinoma of the male breast in Zambia. East Afr Med J. 1972;49:176-9.

6. Incidence of breast cancer in Bangladesh $3^{\text {rd }}$ Indo-Global Summit \& Expo on Healthcare October 05-07, 2015 New Delhi, India Health care: current reviews

7. Frank TS, Deffenbaugh AM, Reid JE, Hulick M, Ward BE, Lingenfelter B, Gumpper KL, Scholl T, Tavtigian SV, Pruss DR, Critchfield GC. Clinical characteristics of individuals with germline mutations in BRCA1 and BRCA2: analysis of 10,000 individuals. J Clin Oncol. 2002; 20:1480-1490. doi: 10.1200/ JCO.20.6.1480. [PubMed] [CrossRef]

8. Friedman LS, Gayther SA, Kurosaki T, Gordon D, Noble B, Casey G, Ponder BA, Anton-Culver H. Mutation analysis of BRCA1 and BRCA2 in a male breast cancer population. Am J Hum Genet. 1997; 60:313-319. [PMC free article] [PubMed]

9. Haraldsson K, Loman N, Zhang QX, Johannsson O, Olsson $\mathrm{H}$, Borg A. BRCA2 germ-line mutations are frequent in male breast cancer patients without a family history of the disease. Cancer Res. 1998; 58: 1367-1371. [PubMed]

10. Misra SP, Misra V, Dwivedi M. Cancer of the breast in a male cirrhotic: is there an association between the two? Am J Gastroenterol. 1996;91: 380-382. [PubMed]

11. Ganly I, Taylor EW. Breast cancer in a trans-sexual man receiving hormone replacement therapy. Br J Surg. 1995; 82:341. doi: 10.1002/bjs.1800820319. [PubMed] [CrossRef]

12. Benchellah Z, Wagner A, Harchaoui Y, Huten N, Body G. Male Breast Cancer, 19 case reports. Ann Chir. 2002; 127:619-623 This article on PubMed

13. Adami HO, Holmberg L, Malker B, Ries L. Long-term survival in 406 males with breast cancer. Br J Cancer. 1985; 52:99-103 This article on PubMed 